\title{
Managing Leadership Skills for Teacher Effectiveness in the Implementation of Early Childhood Education in Federal Capital Territory, Abuja, Nigeria
}

\author{
E.B. Oke \\ Faculty of Education \\ University of Abuja, Nigeria
}

\begin{abstract}
This study assessed the extent leadership skills are managed for teacher effectiveness in the implementation of early childhood education in Federal Capital Territory, Abuja, Nigeria. The study adopted a survey design. Proportionate stratified random sampling method was used to select 240 out of the 559(43 percent) centers as sample as well as subjects. The research instruments tagged: Teacher Leadership Skills Questionnaire (TLSQ) was used for data collection. Percentages and Mean were used to answer the six research questions. Findings indicated that 23 leadership skills are required for teacher effectiveness in the implementation of early childhood education in FCT. Teachers were aware of 13 leadership skills have, access to information on seven of the required leadership skills to a low extent very low extent. Possessed 10 of the required leadership to a low extent. Ten of these skills were frequently used and teachers were motivated to use 10 of the required leadership skills to a low extent Recommendation among others are that early childhood education teachers in FCT need capacity building in the areas skills such as: risk taking, advocacy, learning facilitator, technical skills, financial managing skills, strategic planning skills, creativity and innovative skills, management strategy should ready periodically in order to enable them have full awareness, have access to the information, possess, utilize and also motivated to utilize the required leadership skills for their effectiveness in the implementation of early childhood education in FCT.
\end{abstract}

\section{Introduction}

The Teacher-leadership skill is very imperative in bringing about effective implementation of early childhood education in Nigeria. This implies that it is not enough for the teacher to possess the requisite academic qualification to function at this level; he or she requires other factors that could promote childhood education. Bennett [1] explained that effective teachers are not only technically competent, but they are also creative in discharge of their duties. They also combine good planning, organization, good decision-making technique and knowing how to personally react to their pupils' needs, as well as keep their inter-personal relationship with others intact. These requirements are expected to promote early childhood development.

\section{Meaning and Scope of Early Child Education}

The importance of early childhood education in Nigeria necessitated the establishment of Early Childhood Development (ECD) in 1987 through the efforts of UNICEF and Bernard van LEER in partnership with Federal Government of Nigeria, the Nigerian Educational Research Council (NERC), private sectors and NGOs. The National Policy on education in Nigeria refers to early childhood education as the education given in an educational institution to children between the ages of 3 to 5 years prior to their entering the primary school (Federal Republic of Nigeria [5]. The 2014 edition of the same document splits early childhood education into two-early childhood care, Development and education and Pre-primary Education. The former is divided subdivided into the crèche and nursery/kindergarten classes ( $0-4$ years) while the latter is strictly referred to as pre-primary education expected to be for children aged 5 years. The second segment is expected to last for only one year. However, all these have the same global objectives of care, protection, stimulation and learning promoted in children from age $0-5$ years.

In Nigeria, early childhood education is aimed at developing the cognitive, social, emotional, perceptual, psychomotor language and creative skills of the child. Subsequently, the National policy document articulates the purpose of early childhood education to include the following $(\mathrm{FRN},:)[6]$;

i. Effect a smooth transition from the home to the school

ii. Prepare the child for the primary level of education

iii. Provide adequate care and supervision for the children while their parents are at work (on the farms, in the market, offices, etc.)

iv. Inculate social norms

v. Inculate in the child the spirit of inquiry and creativity through the exploration of nature, the environment, art, music and playing with toys, etc. vi. Develop a sense of cooperation and team spirit. vii. Learn good habits, especially good health habits. 
viii. Teach the rudiments of numbers, letters, colours, shapes, forms etc. through play.

For effective implementation of this level of education, National policy on education [6] articulates that government shall:

i. Set and monitor Minimum Standards for ECCE centers;

ii. Develop and disseminate curriculum materials such as the Integrated Early Child Care Development (IECD) policy. National minimum standard for the establishment of early child Cared Education Centers. IECD curriculum, IECD implementation guidelines and all other materials that will enhance the implementation of ECCDE.

iii. Encourage both community and private efforts in the establishment of ECCDE centers based on set standards.

iv. Make provisions in teacher education programmes for specialization in early childhood care and education, and retraining of teachers;

v. Ensure that the curriculum of teacher education is oriented towards play-way method;

vi. Develop suitable ECCDE curriculum for nationwide implementation

vii. Supervise and control quality of ECCDE centers viii. Make provision for the production and effective utilization of learning and instructional materials in adequate numbers.

ix. Ensure that ECCE Centers adopt the following caregiver-infant ratios-

(a) Day Care Centre shall be 1:10;

(b) Nursery and Kindergarten 1:25;

$x$. Ensure that the medium of instruction is principally the language of the immediate community (mother tongue); and to this end will-

a. Develop the orthography of more Nigerian languages; and

b. Produce textbooks, supplementary and other instructional materials in Nigerian languages.

These policy guidelines are meant to promote this level of education and if teachers would flourish towards bringing about the realization of early childhood education in Nigeria, it is required that they possess and utilize the skills needed to lead.

\section{Statement of Problem}

There is no doubt that early childhood education is imperative for the effective development of any nation's educational system. This had been neglected for a long time due to a number of factors in Nigeria. One of the neglects is mostly felt in the areas of unskillful or inadequate handlers of the children at that critical stage of their lives. This study on teacher -leadership skills for effective implementation of early childhood education in Nigeria is therefore an attempt to find out whether or not the types of skills required, extent of possession and utilization by teachers enhance or inhibit effective implementation of early childhood education in FCT centers. In doing this, the following question is addressed: what type of leadership skills are required and to what extent are teachers aware, possess and utilize these skills for effective implementation of early childhood education in FCT Centers?

\section{Purpose of the Study}

The study aimed at examining teacher leadership skills for effective implementation of early childhood education in Federal Capital Territory (FCT), Abuja-Nigeria. Specifically, the aim of the study includes the following: To

i. find out the types of leadership skills required for effective implementation of early childhood education in FCT centres.

ii. ascertain the extent of teachers' awareness of the required leadership skills for effective implementation of early childhood education in the FCT centers;

iii. establish the extent of access to the information on required leadership skills

iv. examine the extent teachers possess the required leadership skills for effective implementation of early childhood education in FCT centres;

v. ascertain the frequency of teachers utilization of the required skills for effective implementation of early childhood education in FCT centers.

vi. discuss extent teachers motivated to utilize the required leadership skills

\section{Research Questions}

The following research questions were examined in this study:

1. What types of leadership skills teachers required for effective implementation of early childhood education in FCT Centres.

2. What is the level of teachers' awareness of the required leadership skills for effective implementation of early childhood education in FCT centers?

3. Access to the information on required leadership skills

4. What extent do teachers possess the required leadership skills for effective implementation of early childhood education in FCT centers?

5. How frequent do teachers utilize the required leadership skills for effective implementations of early childhood education in FCT centers?

6. How are teachers motivated to

utilize the required leadership skills? 


\section{Concept of Teacher-Leadership}

The concept of teacher-leader is commonly applied to teachers who have taken on leadership roles and additional professional responsibilities. The teacher-leader concept is closely related to voice and shared leadership, or the distribution of leadership roles and decision-making responsibilities beyond the administrative team. For instance, Efoghe [4] stated that a teacher is that person that is ascribed with the full responsibility of managing the classroom in such a way as to enhance the learning behaviour of the students. She explained further that the teacher is concerned with the total development of the child, as well as classroom management. He therefore fulfils several managerial responsibilities in the classroom, which include planning, organizing, directing, leading, as well as reporting Efoghe [4].

As a matter of fact, teachers function as leaders when they are able to function effectively in professional learning communities to impact positively on students' learning, contribute to school improvement, inspire excellence in practice, and empower stakeholders to participate in educational improvement Efoghe [4]. Danielson [3] also posited that teacher leadership is a set of skills demonstrated by teachers who are able to influence students outside of the classroom and beyond. According to Institute for Educational leadership [9], teacher leadership is a mobilization of the available attributes of teachers to strengthen student performance at the ground level.

Teacher leaders work toward collaboration and shared leadership in the daily activities of the school. Katzenmeyer \& Moller [10] also explained that teachers lead within and outside of the classroom. A teacher leader is a member and contributor to a community of teachers' learners. They are influential in the continued improvement of educational practice. Wasley [21] stated that teacher leaders have the ability to encourage other teachers and colleagues to change and begin to think about taking part in things they ordinarily would not consider. The implication of this is that, the teacher has to be well endowed with a number of positive attributes of a leader so as to serve as role models to the pupils, as well as to other teachers around him or her.

For any teacher to be effective in his or her duty as a teacher, he or she needs to possess notable interpersonal relationship skills. There are several of such skills, but Contreras [2] explained some of them as possessing:

- Good communication skill which is the method used to exchange or share information. This implies that teachers have to communicate with the pupils at the early childhood education centres at the children's own level of understanding. This might be cumbersome due to the fact that each child learns and understands at different level and pace. It therefore means that the teacher needs to develop a strategy aimed at reaching these children at their own level.

- Empathy, which implies the ability of the teacher to express care and concern for children generally. This requires the teacher to place him or herself in the position of the children in order to understand their challenges better and then proffer solution to those challenges.

- Positive motivation, which is important because this produces positive learning outcomes in pupils and students. This is based on the fact that some children need extra efforts and positive motivation for their interest to be ignited.

- Ability to deploy effective and positive body language, which is non-verbal communications that leaves a lifelong impression in the minds of the children. Body language also helps to draw children into discussions. This is therefore a powerful tool that maintains healthy interpersonal skills between the teachers and fellow teachers and between the teachers and the children in early childhood education centres.

Humour is another interpersonal skill that allows a teacher to keep the motivational train in motion. As a matter of fact, a well-placed and rightly dispensed humour provides additional motivation and the desire to learn. This means maintaining children's attention is critical to the learning process and humour helps to keep that attention.

\subsection{Leadership Models for Early Childhood education}

Beyond early childhood there is a growing consensus about the methods and approaches which contribute to effective educational leadership development Scottish Executive. There is therefore a wide range of theories on leadership Nivala in Nivala and Hujala, ed, [15]. Many of the authors writing in Nivala and Hujala argue that leadership, change, collaboration and improvement will happen only if there is interaction between leaders and followers. Leadership is often realized in relationships between the leader and the followers and is not just a personal quality but happens in a social context. For instance, the goal setting theory as developed by Victor Vroom explained motivation from two stand points. These are directing attention and prompting action. The highpoint in goal setting theory is geared towards mobilizing efforts, increasing persistence 
and then encouraging development strategies to achieve results. In directing attention, pupils tend to pay closer look at those attributes of the teacher that endear them to the teacher, which helps their development along the way. Prompting action on the other hand involves the measures of activities to be carried out towards ensuring the realization of the goals set out from the outset. This explains the fact that the early childhood schools need to set out attainable objectives, with children's' positive development as major goal, and then, the various steps that could ensure such attainment are pursued to its logical conclusion.

Teacher- leaders are therefore expected to set the standards and the expectations for others to follow. The more recent statements around educational leadership sit well with perceptions held within early childhood that effective early childhood leaders need characteristics and skills which are related to teamwork, motivation, support, role definition and goal setting [17]. Building relationships, organizing and managing resources and time, hiring and managing staff, making genuine connections with children, staff, families, communities and other organisations shared decision-making and empowerment of others are seen as important characteristics of good leadership in early years [15].

In the end, leadership within the ECEC setting is a journey of joint inquiry exploration and reflection that can involve everyone who believes in making a difference for children.

\subsection{Concept and Scope of Skills}

Skills are ability, natural ability to judge something or a sense of direction. Skills are also learned responses derived from specific training which affords someone the ability to perform a particular task and achieve a particular goal. In addition, skills could also be referred to as a welldeveloped capability of any kind, including intellectual physical or artistic capabilities which involves strong imaginative power, mental acuity, visual clarity and conception. Oke [16] also opined that skills are abilities to do something well by learning and practice. He identified three basic skills methods, processes, procedures and techniques of a specialized field to perform specific tasks. Human skill refers to interpersonal skills. It requires an understanding of one's self and group dynamics, and the ability to motivate other people either as individuals or groups.

Conceptual skills is directly associated with knowledge because in order to conceptualize, an individual must possess or have access to a wealth of cognitive interest and activities of the organization cognitive and organized information. Basically, conceptual skills refer to the, mental ability to coordinate and integrate the entire interests and activities of the organization and, more importantly, it also refers to their ability to apply information and concepts to practice. Kingrice [12] sees conceptual skills as the ability to discern meaning in and establish relationships between events and bits of information which at first glance would appear to be discrete and unrelated; it also involves diagnoses and analysis- the ability to quickly get at the true cause of a certain situation through a maze of data, observation and facts.

\subsection{Skills for Effective Implementation of Early Childhood Education}

The aim of teaching is to make pupils/students' learning possible. According to Ramsden [17], teaching is about what and how pupils/students learn; therefore, to teach well implies learning about students' learning. Queensland State Department of Education, Training and Employment stated that teaching is a career that provides challenges, excitement, personal reward and a chance to encourage and support others to achieve their goals. The department affirmed that though the major academic quality of a teacher lies in his or her certification, but many other personal qualities and skills include:

$\checkmark$ Good at explaining subject matter;

Enjoy working with a wide range of people;

Enthusiasm;

Strong knowledge in particular subject areas;

A good time manager;

Ability to work in a team as well as using your own initiative;

$\square$ Ability to work under pressure;

$\checkmark$ Patience and a good sense of humour;

Fair-minded;

$\checkmark$ Coping well with change and challenge.

Furthermore, Sabitu and Balogun [18] contributed that other very important attributes include knowledge of subject matter, communication ability, interest in the job and emotional stability of the teachers, which enable them to impart knowledge effectively to the pupils/students. More also, good teachers know that by listening to and working with colleagues, parents, other professionals and community members, they can inspire and help improve pupils' learning.

Great Teacher [8] offered an explanation from another interesting angle that a great teacher is the one a pupil or student remembers and cherishes all the rest of his/her life. This is because effective teachers often leave lasting impressions on the psyche of their pupils/students, and they also inspire pupils/students toward greatness. This implies that a great teacher should possess the following attributes:

i. Passion for children and teaching so as to positively influence their lives; 
ii. Clear objectives that could meet specific objectives of each class activity;

iii. Possess effective skills that can promote positive behaviours and needed change;

iv. An engaging personality and teaching style that can hold students' attention always;

v. Possess high expectations of students and encourage them to always be at their best;

vi. Possess good management skills and an overall sense of respect in the classroom;

vii. Knowledgeable in curriculum and standards and ensuring they meet those standards.

viii. Knowledgeable in subject matters to improve pupils' academic development;

ix. Strong rapport with students and establishes trusting relationships.

x. Good communication with parents and keeps them informed about their children, as well as making themselves available for phone calls, meetings, and emails.

King-Rice [12] affirmed that the above qualities are imperative for a teacher in the sense that it is the livewire that determines teacher's ability to deliver on the job. Additionally, Teacher Registration Council of Nigeria TRCN, [20] set up professional standards for Nigerian teachers which consist of four themes to be used to appraise the professional standing of a teacher in Nigeria. These are:

a) Professional Knowledge,

b) Professional Skills,

c) Professional Values, Attitudes and Conduct, and,

d) Professional Membership Obligations

The four (4) Themes are broken down into thirtysix (36) sub-themes and then into eighty-four (84) standards. The standards are essentially performance benchmarks expected of professional teachers in Nigeria, depending on the category of the teachers. The personal disposition and attitudes of a leader play a very important part in the execution or performance of his roles. The personality traits if the individual leader connotes such attributes as intelligence, initiative, supervisory ability, selfassurance, affinity for the working class, decisiveness, maturity, etc. personality trait formed the basis for the earliest studies on leadership. Such studies perceived leadership ability as personality gift.

The proponents of this personality approach were carried away by their belief that one's behavior is a product of his personality; that good leaders could be identified or isolated due to their personality. It was believed that some people are naturally born to lead and others to follow. Generally, it is believed that the personal characteristics, as well as skills of a leader would have some relationship with his behaviors which in turn determine the performance of his/her roles. Although skills are organized by construct, many of the skills identified can be placed into several categories. These skills are briefly described below:

Work ethic: Teacher leaders have been described as perseverant, resourceful, action- oriented committed and passionate. Danielson [3] averred that the passion they have for their mission allows teacher leaders to find the courage to persist in the face of adversity and obstacles. Kyllonen, Lipnevich, Burrus, \& Roberts [13] noted that this skill, with its close links to conscientiousness, has been demonstrated in meta-analytic studies to be one of the best predictors of workplace performance across a range of occupations.

Teamwork: This simply affirms the fact that teacher leaders need work with many constituencies (to improve teaching practice and promote positive change within the larger learning community). YorkBarr \& Duke [22] stated that it is important that teachers-leaders possess the ability to build solid relationships with colleagues, parents, students, administration, and the community. To build such relationships, they should be able to engender trust, work well with colleagues, communicate effectively, and resolve conflict [3], [11].

Leadership: Teacher leaders should lead by engaging, inspiring, and motivating others to improve and become better through their actions. They should be able to lead by effectively communicating with colleagues and informing them of their goals in ways that garner support for their vision for the school [3].

Openness: Teacher leaders are adaptable, openminded, and creative. They should be open to exploring options to gather the necessary resources to improve the state of education, especially at the early childhood stage, which they oversee [22]. Furthermore, teacher leaders are able to adapt and adjust to situations through their creativity and flexibility [3].

Vision: Related to the concept of openness to new ideas, a good teacher leader should possess enough vision to be able to identify opportunities for improvement or to fix problems within the school. They should endeavour to actively seek out such opportunities rather than simply waiting for them to appear [3]. They also have the ability to see the big picture and how what they are doing fits into the larger goal of pupils' learning (York-Barr \& Duke, [22]).

Positive affect: Positive emotions have been demonstrated to have a number of beneficial outcomes. Fredrickson [7] asserted that the presence of positive emotions can help people to think more creatively, deal with stressful situations, be more engaged in activities, and build social relationships. As such, it is not surprising that successful teacher leaders often succeed with the help of positive affect. Their tendency to display optimism, enthusiasm, and 
confidence leads others to think creatively and work together to solve problems (Danielson, [3].

Risk taking: Teacher leaders are willing to take risks in order to achieve their goals. They are willing to take the chance to attempt new and innovative initiatives despite the fact that what they are doing may end up failing and expose them to external criticisms (Danielson, [3].

Teaching related skills: Teacher leaders are also good teachers. They display outstanding teaching skills [16] hold a comprehensive philosophy of education, and are relatively altruistic [10]. Furthermore, they have a deep understanding of various theories and practices of teaching [11]. Teacher leaders are willing to expand their role as teacher to develop their career, and have the time, energy, and patience required to assume such a role [22].

According to WaMu [14], views teachers leadership skills in terms of the knowledge and skills needed, disposition and roles and opportunities of teacher leaders. The skills teacher leaders need to be effective in a variety of roles can be broken into five main categories such as:

i. Working with adult learners

ii. Communication

iii. Collaboration

iv. Knowledge of content and pedagogy

v. Systems thinking.

Noteworthy is the fact that the foundation in the educational life of the child is laid at the early years and how far the child could go educationally depends on how strong the foundation is. This means if a child is denied good education at the early stage; it is difficult for the child to fit appropriately into tertiary education later in life. The lesson here is that Early Childhood Care and Education (ECCE) is very critical and sustains a child's lifelong educational potential.

\section{Research Methodology}

The purpose of this study was to assess teacher leadership skills for effective implementation of early childhood education in Nigeria. The study adopted a survey design that elicited responses from a total population of 559 early childhood centers across the six Area Councils in FCT, Abuja. Proportionate stratified random sampling method was used to select 43 percent of the entire 559 centers representing 240 centers across the 6 area councils in FCT. The 240 head teachers serve as the respondent for the study. Researcher-designed instruments tagged: Teacher Leadership Skills Questionnaire (TLQ), was administered for data collection. The instrument had a total of four sections with 23-item questions. Each section sought information on various types of teachers' leadership skills required, extent of awareness possession and utilization by teachers. The response categories were designed along modified Likert rating scale of Strongly Agree (4 points) [SA], Agreed (3 points) [A], Disagree (2 points) [D], Strongly Disagree (1point) [SD] for research question 1 while Very Great Extent (VGE), 4 points, Great Extent (GE), 3 points, Low Extent (LE), 2 points and Very Low Extent (VLE), 1 point were used to answer research questions 2 and 3. Respondents (head teachers) were required to indicate their options regarding the types of skills required, possessed and utilized by teachers on the modified likert rating scales. The instrument was validated by head teachers and specialist from University of Abuja. A pilot study was carried out with two early childhood centers outside the actual samples. The Pearson Product Moment Correlation Coefficient format was used to determine the reliability of the instrument. A reliability score of 0.63 was obtained which was considered high enough for the instrument. Two hundred and forty (240) copies of the questionnaire were distributed. Data collected for the study were analyzed using frequencies, mean scores. The decision rule is 2.5 which means any mean that is 2.5 and above is considered positive while below is considered negative

\subsection{Interpretation of Results}

1. What types of leadership skill are required for the effective implementation of early childhood education in the Federal Capital Territory?

Table 1: Mean scores of the Required leadership skills for effective implementation of early childhood education in FCT Centres. $\mathrm{N}=240$

\begin{tabular}{|l|l|c|l|}
\hline $\begin{array}{l}\text { S/ } \\
\text { N }\end{array}$ & $\begin{array}{l}\text { Required Teacher- } \\
\text { Leadership Skills }\end{array}$ & Mean & $\begin{array}{l}\text { Decisio } \\
\text { n }\end{array}$ \\
\hline 1 & $\begin{array}{l}\text { Personal } \\
\text { disposition/attitudes } \\
\text { skill }\end{array}$ & 3.32 & Agree \\
\hline 2 & Risk taking skill & 3.33 & Agree \\
\hline 3 & Humanitarian skill & 3.44 & Agree \\
\hline 4 & Advocacy skill & 3.47 & Agree \\
\hline 5 & $\begin{array}{l}\text { Mentoring/counseling } \\
\text { skill }\end{array}$ & 3.37 & Agree \\
\hline 6 & $\begin{array}{l}\text { Instructional resource } \\
\text { management }\end{array}$ & 2.84 & Agree \\
\hline 7 & Leadership skill & 3.41 & Agree \\
\hline 8 & $\begin{array}{l}\text { Interpersonal } \\
\text { relationship skill }\end{array}$ & 3.38 & Agree \\
\hline 9 & Learning facilitation skill & 2.56 & Agree \\
\hline 10 & Communication skill & 3.33 & Agree \\
\hline 11 & Technical skill & 2.52 & Agree \\
\hline 12 & Collaborative skill & 3.18 & Agree \\
\hline 13 & $\begin{array}{l}\text { Organization/administra } \\
\text { tive skill }\end{array}$ & 2.85 & Agree \\
\hline 14 & $\begin{array}{l}\text { Content knowledge and } \\
\text { classroom application } \\
\text { skill }\end{array}$ & 3.33 & Agree \\
\hline 15 & $\begin{array}{l}\text { Assessment/evaluative } \\
\text { skill }\end{array}$ & 3.17 & Agree \\
\hline 16 & Decision making skill & 3.82 & Agree \\
\hline 17 & $\begin{array}{l}\text { Financial management } \\
\text { skill }\end{array}$ & 2.92 & Agree \\
\hline 18 & Goal setting skill & 3.50 & Agree \\
\hline 19 & Strategic planning skill & 3.64 & Agree \\
\hline 20 & Motivational skill & 3.28 & Agree \\
\hline 21 & Problem solving skill & 3.04 & Agree \\
\hline 22 & Creativity and innovative & 2.53 & Agree \\
\hline 23 & ime management skill & 3.42 & Agree \\
\hline & Grand Mean & 3.47 & Agree \\
\hline & & \\
\hline
\end{tabular}


Table 1 depict average mean score of 3.47. All the 23 items scored Agree, the mean score ranging between 2.56-3.64 which is an indication that all the 23 items leadership skills in this table are required for effective implementation of early childhood education in FCT centres.

Table 2: Means scores of Teachers' extent of Awareness of required Leadership Skills N=240

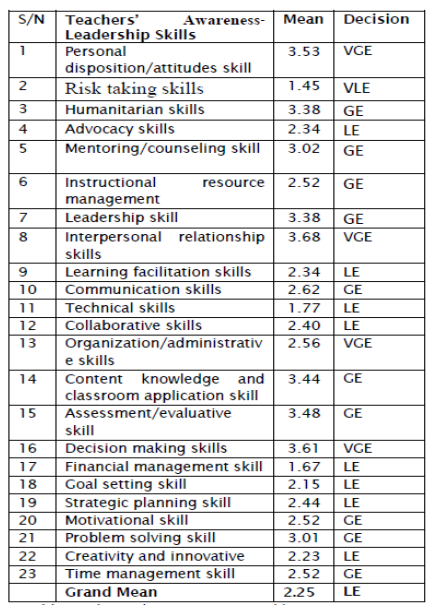

Table 2 shows items 1,8,13,16 with mean scores ranging from 3.53-3.68. teachers are aware of such items to a very great extent. While items $3,6,7,10,14,15,20,21,23$ mean scores range from 2.52-3.48 teachers' awareness are to great extent. However, items 4,9,11,12,17,18,22(mean score 1.672.40) and item 2 with mean score 1.45 teachers' awareness are to a low and very low extent. The average mean is 2.25 awareness to a low extent.

Table 3: Extent Teacher have Access to Information on the Required Leadership Skills. N=240

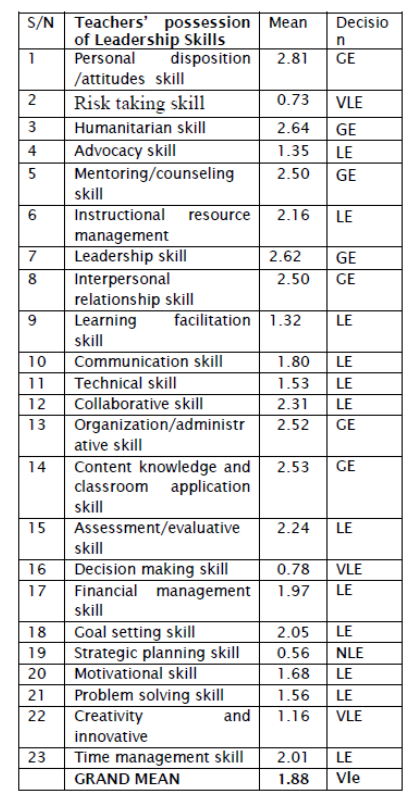

Table 3 depicts 7 items in No 1,3,5,7,13,14 as teacher's access to information on knowledge of skills to a great extent while the other 17 items in Nos. 2,4,6,8,9,10,11,12,15,16,17,18,19,20,21,22,23 showed that teachers have very low students and low no access to information in the required skills.

Table 4: Extent of Teachers Possession of the Required Leadership Skills. N=240

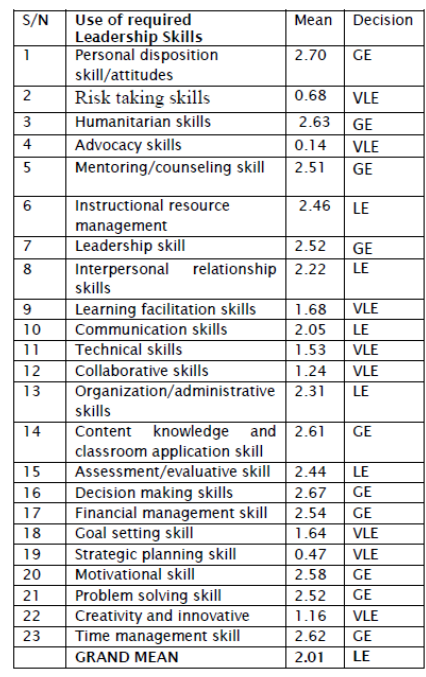

Table 4 depicts an average mean score of 2.01. it shows that teachers generally possess the leadership skills to a low extent. However, items $1,3,5,7,14,16,17,20,21$ and 23 have mean scores ranging from $2.51-2.70$ show that teachers possess such items to a great extent while items $6,8,10,13,15$ (mean score 2.05-2.46), possess to a low extent and items $2,4,9,11,12,18,19$ and 22 mean scores $(0.14$ 1.68) possess to a very low extent.

Table 5: Extent of Teachers' Frequency use of required Leadership Skills. N=240

\begin{tabular}{|c|c|c|c|}
\hline $5 / \mathrm{N}$ & $\begin{array}{l}\text { Use of required } \\
\text { Leadership Skills }\end{array}$ & Mean & Decision \\
\hline 1 & $\begin{array}{l}\text { Personal disposition } \\
\text { skill/attitudes }\end{array}$ & 2.70 & $\mathrm{~F}$ \\
\hline 2 & \begin{tabular}{|l} 
Risk taking skills \\
\end{tabular} & 0.34 & NVF \\
\hline 5 & \begin{tabular}{|l|l|} 
Humanitarian skills \\
\end{tabular} & 2.60 & $\mathrm{~F}$ \\
\hline 4 & \begin{tabular}{|l} 
Advocacy skills \\
\end{tabular} & 0.00 & NVF \\
\hline 5 & \begin{tabular}{|l|} 
Mentoring/counseling skill \\
\end{tabular} & 2.52 & $\mathrm{~F}$ \\
\hline 6 & $\begin{array}{l}\begin{array}{l}\text { Instructional resource } \\
\text { management }\end{array} \\
\end{array}$ & 1.73 & $\mathrm{NF}$ \\
\hline 7 & Leadership skill & 2.01 & $\mathrm{NF}$ \\
\hline 8 & 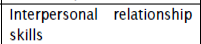 & 0.56 & NVF \\
\hline 9 & Learning facilitation skills & 0.00 & NVF \\
\hline 10 & Communication skills & 1.28 & $\mathrm{NF}$ \\
\hline 11 & Technical skills & 1.51 & $\mathrm{NF}$ \\
\hline 12 & Collaborative skills & 0.74 & NVF \\
\hline 13 & $\begin{array}{l}\begin{array}{l}\text { Organization/administrativ } \\
\text { e skills }\end{array} \\
\end{array}$ & 1.83 & $\mathrm{NF}$ \\
\hline 14 & $\begin{array}{l}\text { Content knowledge and } \\
\text { classroom application skill }\end{array}$ & 2.51 & $\mathrm{~F}$ \\
\hline 15 & $\begin{array}{l}\begin{array}{l}\text { Assessment/evaluative } \\
\text { skill }\end{array} \\
\end{array}$ & 2.41 & $\mathrm{NF}$ \\
\hline 16 & \begin{tabular}{|l} 
Decision making skills \\
\end{tabular} & 2.54 & $F$ \\
\hline 17 & \begin{tabular}{|l} 
Financial management skill \\
\end{tabular} & 2.51 & $\mathrm{~F}$ \\
\hline 18 & Goal setting skill & \begin{tabular}{|l|l|}
0.86 \\
\end{tabular} & NVF \\
\hline 19 & \begin{tabular}{|l} 
Strategic planning skill \\
\end{tabular} & \begin{tabular}{|l|}
0.64 \\
\end{tabular} & NVF \\
\hline 20 & Motivational skill & 2.58 & \\
\hline 21 & \begin{tabular}{|l} 
Problem solving skill \\
\end{tabular} & 2.50 & \\
\hline 22 & Creativity and innovative & 0.73 & NVF \\
\hline 23 & Time management skill & 2.54 & 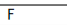 \\
\hline & GRAND MEAN & 1.63 & $\mathrm{NF}$ \\
\hline
\end{tabular}


Table 5 show an average mean of 1.63 in terms teacher's frequency use of the required leadership skills. This means the leadership skills are not frequently used. Notwithstanding, items $1,3,5,14,16,17,20,21,23$ mean sore (2.50-2.70) are frequently used for ECEC implementation while items 7,10,15,6,13 with mean score (1.28-1.83) and items $2,4,8,11,12,18,19,22$ with mean score ranging from $0.00-0.86$, their use were neither frequent and/or never used frequently.

Table 6: Mean Scores of the Extent Teachers are Motivated to use leadership skills. $\mathrm{N}=240$

\begin{tabular}{|r|l|l|l|}
\hline S/N & $\begin{array}{l}\text { Use of required } \\
\text { Leadership Skills }\end{array}$ & Mean & Decision \\
\hline 1. & $\begin{array}{l}\text { Personal disposition } \\
\text { skill/attitudes }\end{array}$ & 2.56 & GE \\
\hline 2. & Risk taking skills & 2.03 & LE \\
\hline 3. & Humanitarian skills & 3.56 & VCE \\
\hline 4. & Advocacy skills & 1.73 & LE \\
\hline 5. & Mentoring/counseling skill & 0.82 & VLE \\
\hline 6. & $\begin{array}{l}\text { Instructional resource } \\
\text { management }\end{array}$ & 2.55 & GE \\
\hline 7. & Leadership skill & 3.24 & VGE \\
\hline 8. & $\begin{array}{l}\text { Interpersonal relationship } \\
\text { skills }\end{array}$ & 3.05 & VGE \\
\hline 9. & Learning facilitation skills & 2.43 & LE \\
\hline 10. & Communication skills & 3.05 & VCE \\
\hline 11. & Technical skills & 2.43 & LE \\
\hline 12. & Collaborative skills & 3.25 & GE \\
\hline 13. & $\begin{array}{l}\text { Organization/administrative } \\
\text { skills }\end{array}$ & 0.62 & VLE \\
\hline 14. & $\begin{array}{l}\text { Content knowledge and } \\
\text { classroom application skill }\end{array}$ & 1.85 & VLE \\
\hline 15. & Assessment/evaluative skill & 2.61 & GE \\
\hline 16. & Decision making skills & 2.57 & LE \\
\hline 17. & Financial management skill & 2.16 & LE \\
\hline 18. & Goal setting skill & 1.94 & VLE \\
\hline 19. & Strategic planning skill & 0.65 & VLE \\
\hline 20. & Motivational skill & 1.73 & VLE \\
\hline 21. & Problem solving skill & 0.45 & VLE \\
\hline 22. & Creativity and innovative & 2.51 & GE \\
\hline 23. & Time management skill & 0.94 & VLE \\
\hline & GRAND MEAN & 2.63 & VLE \\
\hline & & \\
\hline & & \\
\hline
\end{tabular}

Table 6 depict average mean score of all items in item $1,3,6,7,8,10,12,13,20$ and 23 ranging from 2.55-3.25 showed that teachers are motivated to utilized the skills of the skills while it items are not motivated to utilized the items for implementation of early childhood education.

\section{Findings of the study}

The study showed that twenty-three (23) leadership skills are required for effective implementation of ECEC in FCT centres with an average mean score of 3.47 (see Table 1). The extent of the awareness of teachers about the required leadership skillswas found to be low with a grand mean score of 2.25. However, they have the awareness of the need of 13 leadership skills but unaware of 10 (ten) of such skills (see Table 2).

Teachers access to information on required leadership skills is with a very low extent. They have access to information to only ten skills. (see table 3 ). Furthermore, the extent of teachers' possession of required leadership was low with an average mean of 2.01. Out of the 14 leadership skills, teachers are aware of, they were found to possessed ten (10) of these skills. While the remaining 13 leadership skills are either not possess at all or possess to a very low extent (see Table 4).

In addition, it was found that teachers use of the possessed leadership skills were not frequent with an average mean score of 1.63 (Table 5). Teachers frequently used nine (9) of the required skills while 14 of such skills were neither frequently utilized nor never used at all in implementation of early childhood education in FCT centres. Extent of teachers motivation to use required leadership skills with grand mean score of 2.12. however, teachers were motivated to use ten leadership skills.

\section{Discussion of findings}

It was found in this study that the leadership skills required by teachers for the effective implementation of early childhood education 23 in number which includes but not limited to personal disposition/attitudes, risk taking, advocacy, humanitarian, communication, collaboration, content knowledge and classroom management, creativity and innovation, instructional resource management, leadership, administration, assessment, decision making, goal setting, strategic planning, motivation, problem solving, financial management, time management, mentoring/counseling. This finding agrees with York-Barr \& Duke [20] and Danielson [3] who regarded these skills as necessary for effective implementation of an education programme.

The finding also established the skills teachers are aware of the need of personal disposition and attitude, humanitarian skills, mentoring and counseling, instructional resource management, leadership, interpersonal relationship skill, communication skill. Organization skill, content knowledge and classroom management, assessment/evaluative, decision making, motivational skills, problem solving skills and time management skills.

Also it was found that skills possessed by teachers are personal disposition/attitude, humanitarian skills, mentoring and counseling skills, leadership skills, content knowledge and classroom application skills, decision making skill, financial management skill, motivational skill, problem solving skill, time management skill in early childhood education centres in FCT. This finding agrees with Ramsden [15], Sabitu and Balogun [16] based on the fact that without these skills, a teacher could hardly function in the discharge of his or her duties.

Another finding was that the teachers frequently utilize leadership skills such as personal disposition/attitude skill, humanitarian skill, mentoring and counseling skill, content knowledge 
and classroom management skill, decision making skill, financial management skill, problem solving skill and time management skill. This agrees with Wasley [19] and Contreras [2] who believed strongly that utilization of these skills can aid the abilities of the teacher to communicate better.

However, awareness of teachers of the need of the following skills were found to be at a very low extent; risk taking, advocacy skills, interpersonal relationship, learning facilitation skills, collaborative skill, goal setting skill, strategic planning skill and creativity and innovative skill, in the same way, teachers were found not tom possess the following leadership skills; instructional resource management, communication skill, technical skill, assessment and evaluative skill, creativity and evaluative skill and could not frequently utilize the leadership skills mentioned above. This finding simply reaffirmed the findings of Danielson [3] and that of Sabitu and Balogun [16] because they have already established in their separate works on the positive influence of leadership skills on teacher performance.

The objectives of early childhood education is anchored in the convention on the rights of the child particularly the right to develop to the "maximum extent possible". The objectives emphasize the total development of the child through two major instrument; health and nutrition on one hand and physical, social and psychological stimulation on the other. The latter is directly relevant to building in the child capacity to function and adapt to the subjective world of persons and its vagaries. No less important is the child's competence at adapting to the objective world that is the behavior of objects and matter without a teacher.

It is often also stated that education can rise above the level of the teacher. It is also stated that the children have wings. It is the teachers that can help them to fly.

Teachers cannot help if they themselves are not aware of the required skills or do not possess the skills adequately and utilized the needed skills for effective implementation of ECE.

This has great implication for teacher education programme particularly early childhood teachers in Nigeria.

\section{Conclusion and Recommendations}

Based on the findings of this study, it is reasonable to conclude that the need assessment or awareness of required skills, provision of various access to information of the required skills, possession and utilization of leadership skills by teachers adequate motivation to use the skills are all desirable and could bring about effective implementation of early childhood education. People perish for lack of knowledge. It is a known fact that knowledge is power. One can only meet or desire the need that has been assessed or identified. You cannot give what you do not have and can't have what you do not know that you need or lack. Teachers should be made to be aware of the required skills they need for effective implementation and means and strategies for them to possess and utilize them should be provided.

Based on the findings, the recommendations proposed are that:

- Teachers need leadership training periodically in order to keep pace with contemporary leadership skills, they need training on interpersonal relationship in workshops and seminars so that their approach to individuals could be improved, there is need for in-service training and retraining in early childhood education for the teachers so as to be abreast with how best to handle children in FCT centres.

- Teachers should be given awareness or exposed to indepth knowledge of the skills they require for them to be effective in teaching and learning activities.

- Furthermore, Nigerian government should make provision in every teacher education programmes for specialization of early child care and education to assist teachers acquire the necessary skills and develop strategies for performance in reaching out to the children. Head teachers should embark on regular supervision so as to identify the areas of strength and weakness of these teachers and develop ways to ameliorate them.

- All the Colleges of Education and other NCE awarding institutions should introduce a programme on Early Childhood Education.

- Government should infuse a programme of Early Childhood Care Education into the curriculum of teachers education at the NCE level, since the minimum teaching qualification in Nigeria Certificate in Education.

- Training and retraining of care givers/teachers should be made a vital part of the education process.

- Regular workshop, seminars and conferences on Early Childhood Education should be organized for teachers/caregivers in Nigeriato keep them abreast of current innovations and best practices in the field.

- In reviewing the National Policy on Education, effort should be made to spell out in clear terms the policy on Early Childhood Care Education and care, with appropriate mechanism put in place to monitor the implementation of the policy by the providers. 


\section{References}

[1] Bennett, R. (2010). Social characteristics of effective teachers. Retrieved on 5/07/2016 from http://cw.routledge.com/textbooks/

[2] Contreras, M. (2016). Interpersonal skills for teachers. Retrieved on 07/07/2016 from http://www.interpersonal skillsonline.com/.

[3] Danielson, C. (2006). Teacher leadership that strengthens professional practice. Alexandria, VA: Association for Supervision and Curriculum Development.

[4] Efoghe, H.O. (1994). Professionalizing teaching. Lecture Series of the Edo State University, Ekpoma.

[5] Federal Republic of Nigeria (2004). National Policy on education, Abuja: NERDC Press

[6] Federal Republic of Nigeria, (2014). National policy of education, 4th Edition NERDC Press.

[7] Fredrickson, B.L. (1998). What good are positive emotions? Review of General Psychiatry, 2, 300-319.

[8] Great Teacher (2012). What makes a great teacher? Retrieved 05/07/2016 from http://www.greatschools.org/ improvement/quality-teaching/

[9] Institute for Educational Leadership. (2001). Leadership for student learning: Redefining the teacher as leader. Retrieved 07/07/2016 from http://www.iel.org/pdf.

[10] Katzenmeyer, M., \& Moller, G. (2001). Awakening the sleeping giant: Helping teachers develop as leaders (2nd ed.). Thousand Oaks, CA: Corwin Press.

[11] Killion, J., \& Harrison, C. (2006). Taking the lead: New roles for teachers and school-based coaches. Oxford, OH: National Staff Development Council.

[12] King-Rice, J. (2003). Understanding the effectiveness of teacher attributes Retrieved on 05/07/2016 from http://www.epi.org/publication/books/

[13] Kyllonen, P. C., Lipnevich, A. A., Burrus,J., \& Roberts, R. D. (2010). Personality, motivation, and college readiness: A prospectus for assessment and development. Princeton, NJ: ETS.

[14] Center for strengthening the Teaching Profession. (2009). WaMu JP Morgan Chase. from www.cstp-wa.org.

[15] Nivala, V. \& Hujala, E. (Eds) (2002). Leadership in early childhood education - Cross cultural perspectives. Acta Universitatis Ouluensis. Series E 57. Oulu: University Press.

[16] Oke E.B. (2018) Teacher Leadership Skills for Effective Implementation of Early Childhood in Federal Capital Territory. LICE-WCSNE proceedings. LICE WCSNE, London International Conference on Education (LICE-2018) in collaboration with world congress on Special Needs Education (WCSNE-2018). December 10-
13,2018, Cambridge, UK. LICE-WCSNE @ 2018 Published by Infonomics Society. ISBN: 978-1-90832098-8 ISBN: 978-1-908320-99-5. 51-63.

[17] Ramsden, D. (1992). Characteristics of good teaching. Retrieved on 05/02/2015 from http:// www.iml.uts.edu.au/learn-teach/goodteaching.html

[18] Sabitu, A.O. and Balogun, B. N. (2010). Teachers' attributes as correlates of students' academic performance in geography in the secondary schools in Ondo State, Nigeria. Pakistan Journal of Social Sciences, 7(5), 388392.

[19] Teacher Registration Council of Nigeria (2012). The teaching profession Decree No. 31 of 1993. The Federal Ministry Education, Nigeria.

[20] Wasley, P. A. (1991). Teachers who lead: The rhetoric of reform and realities of practice. New York, NY: Teachers College Press.

[21] York-Barr, J., \& Duke, K. (2004). What do we know about teacher leadership? Findings from two decades of scholarship. Review of Educational Research, 74, 255316.

\section{Acknowledgements}

Thanks to God Almighty for opportunity granted to attend the conference. I appreciate Prof. Charles Shoniregun for the privilege to chair Teacher Education Session and IJIBS for accepting to publish my paper. The Management of the University of Abuja, my family, colleagues, selected centers are appreciated for their encouragement. 